\title{
PATHOGENICITY OF A FIELD MAREK'S DISEASE VIRUS ISOLATE (VUB-83) FOR CHICKENS OF THREE GENETICALLY DIFFERENT TYPES
}

\section{JURAJDA and R. HALOUZKA}

Department of Poultry, Fish, Bee and Game Animal Diseases

Department of Pathomorphology and Parasitology

University of Veterinary Science, 61242 Brno

Received October 7, 1988

\begin{abstract}
Jurajda V., R. Halouzka: Pathogenicity of a Field Marek's Disease Virus Isolate (VUB-83) for Chickens of Three Genetically Different Types. Acta vet. Brno, 58, 1989: 273-279.

The incidence of Marek's disease (MD) after parenteral infection of chickens of three genetically different types (Hybro pullets, final White Hisex hybrids and Brown Leghorn chickens) with a field isolate (VUB-83) of $\mathrm{MD}$ virus was followed under laboratory conditions. MD was diagnosed on the basis of gross lymphomas or, in their absence, on the basis of histological examination in chickens that died during the 105-day observation period.

The incidence of MD lymphomas in chickens that died and the mean time to death showed significant differences between the three groups in the following order: Hybro (95.8\%; 78.1 days), Hisex (75\%; 55.5 days) and $\operatorname{BrL}(57.2 \% ; 43.1$ days). Total mortality and the incidence of MD was lowest in Hybro pullets $(63.2 \%$ and $68.4 \%$ ), differing significantly from the values observed in Hisex $(94.1 \%$ and $94.1 \%)$ and $\operatorname{BrL}(95.6 \%$ and $100 \%)$ chickens. The total incidence of MD lymphomas showed no significant differences between the three groups (Hybro, $65.8 \%$; Hisex, $70.6 \%$; BrL, $53.3 \%$ ). In all the chickens tested the most frequently tumour-affected organs after infection with isolate VUB-83 were the liver $(34.7 \%)$ and the spleen $(29.5 \%)$. The early mortality syndrome was not observed.
\end{abstract}

Very virulent pathotypes of Marek's disease virus, genetic susceptibility, mortality, MD lymphomas

The incidence of Marek's disease in poultry flocks is influenced by factors associated with both the host and the environmental conditions. A major ecological factor is the degree of pathogenicity of the causative agent - Marek's disease virus (MDV). A number of studies have demonstrated the existence in poultry populations of MDV strains of different pathogenicity, ranging from apathogenic to highly virulent strains characterized by increased oncogenicity for both vaccinated and unvaccinated chickens regardless of their genetic susceptibility or resistance (Witter et al. 1980; Eidson et al. 1981; Powell and Lombardini 1986).

The present study was designed to assess the virulence of a field MDV strain 
isolated from a flock of pullets vaccinated with turkey herpesvirus vaccine and affected with the acute form of MD (Jurajda and Halouzka 1988) for chickens of three genetically different types.

\section{Materials and Methods}

Included in the experiment were meat-type Hybro pullets (waste product of the parental line of a grand-parental flock) and layer-type final White Hisex hybrid chickens, both produced commercially by Drůbežnictví Xaverov, and leucosis-free Brown Leghorn (BrL) chickens susceptible to MD (Biggs and Payne 1963; Jurajda et al. 1988) obtained from the Institute of Molecular Genetics, Prague.

Chickens of these 3 genetically different types were infected i.m. with field isolate VUB-83 in the form of a cell-free inoculum from feather follicle extract in the dose of $0.1 \mathrm{ml}$ (Jurajda and Halouzka 1988) on the 2nd post-hatching day.

In chickens that died MD was diagnosed on the basis of gross tumours or MD-specific microscopic changes. In birds that survived up to the 105th day of the experiment and were then killed MD was diagnosed only on the basis of tumours.

Histological examination of the peripheral nerves, gonads, bursa Fabricii, thymus, spleen and the skin was carried out with routine methods. Sections, $5 \mu \mathrm{m}$ thick, were stained with haematoxylin and eosin.

The significance of the results was assessed by the chi-squared test according to Reisenauer (1965) at $\mathrm{P}<0.05$.

\section{Results and Discussion}

The present study is a continuation of the biological characterization in vivo of MDV field isolate VUB-83 that is characterized by increased oncogenicity for chickens vaccinated with turkey herpesvirus vaccine (Jurajda and Halouzka 1988). Our investigations were carried out for 15 weeks and covered the mortality, mean time to death incidence of MD-lymphomas and the total incidence of MD in parenterally infected commercial chickens of differing susceptibility to MD (White Hisex and Hybro) and in a laboratory line of $\mathrm{BrL}$ chickens highly susceptible to MD (Biggs and Payne 1963; Jurajda et al. 1988).

Table 1. Mortality, mean time death and the incidence of Marek's disease in 3 genetically different groups of chickens evaluated 105 days after infection with a field isolate (VUB-83) of Marek's disease virus

\begin{tabular}{|c|c|c|c|c|c|c|}
\hline \multirow{3}{*}{$\begin{array}{r}\text { Group } \\
\text { HYBRO }\end{array}$} & \multicolumn{2}{|c|}{ MD-mortality } & \multirow{2}{*}{$\begin{array}{c}\varnothing \text { time } \\
\text { death (days) }\end{array}$} & \multicolumn{3}{|c|}{ Total } \\
\hline & Tumours & Total & & Tumours & & D \\
\hline & $23 / 24^{1} \mathrm{a}^{2}$ & $24 / 38$ a & $78.1 \mathrm{a}$ & $25 / 38$ & $26 / 38$ a & $68.42 \%$ \\
\hline HISEX & $24 / 32$ b & $32 / 34 \mathrm{~b}$ & $55.5 \mathrm{~b}$ & $24 / 34$ & $32 / 34 \mathrm{~b}$ & 94.12 \\
\hline $\mathrm{BrL}$ & $22 / 43 \mathrm{c}$ & $43 / 45 \mathrm{~b}$ & $43.1 \mathrm{c}$ & $24 / 45$ & $45 / 45 \mathrm{~b}$ & 100.00 \\
\hline
\end{tabular}

1 No. positive/No. examined

? Values indicated with different letters are significantly $(P<0.05)$ different 
Table 2. Distribution and frequency of the incidence of tumours in 3 genetically different groups of chickens 105 days after infection with a field isolate (VUB-83) of Marek's disease virus $^{1}$

\begin{tabular}{|c|c|c|c|c|c|c|c|c|}
\hline Organ & \multicolumn{2}{|c|}{$\begin{array}{c}\text { HYBRO } \\
73 / 25^{3}\end{array}$} & \multicolumn{2}{|c|}{$\underset{60 / 24}{\text { HISEX }}$} & \multicolumn{2}{|c|}{$\begin{array}{c}\mathrm{BrL} \\
60 / 24\end{array}$} & \multicolumn{2}{|c|}{$\begin{array}{c}\text { Chickens }^{2} \\
193 / 73\end{array}$} \\
\hline $\begin{array}{l}\text { Liver } \\
\text { Spleen } \\
\text { Kidney } \\
\text { Proventriculus } \\
\text { Gonads } \\
\text { Heart } \\
\text { Lung } \\
\text { Muscle }\end{array}$ & $\begin{array}{r}21 \\
20 \\
13 \\
5 \\
6 \\
3 \\
4 \\
4 \\
1\end{array}$ & $\begin{array}{r}28.77 \\
27.40 \\
17.81 \\
6.85 \\
8.22 \\
4.11 \\
5.48 \\
1.37\end{array}$ & $\begin{array}{r}21 \\
18 \\
9 \\
7 \\
2 \\
3 \\
\\
-\end{array}$ & $\begin{array}{r}35.00 \\
30.00 \\
15.00 \\
11.67 \\
3.33 \\
5.00\end{array}$ & $\begin{array}{r}25 \\
19 \\
9 \\
2 \\
2 \\
3 \\
- \\
-\end{array}$ & $\begin{array}{r}41.67 \\
31.67 \\
15.00 \\
3.33 \\
3.33 \\
5.00\end{array}$ & $\begin{array}{r}67 \\
57 \\
31 \\
14 \\
10 \\
9 \\
4 \\
1\end{array}$ & $\begin{array}{r}34.72 \\
29.53 \\
16.06 \\
7.25 \\
5.18 \\
4.66 \\
2.07 \\
0.52\end{array}$ \\
\hline $\mathrm{Ti}^{4}$ & \multicolumn{2}{|c|}{2.9} & \multicolumn{2}{|c|}{2.5} & \multicolumn{2}{|c|}{2.5} & \multicolumn{2}{|c|}{2.6} \\
\hline
\end{tabular}

1 No. positive findings; expressed in percentages

2 Total distribution and frequency of the incidence of tumours after infection with isolat VUB-83 in all chickens tested

3 Total No. tumour-altered organs/No. chickens with tumours

4 Tumour index $=$ mean No. tumour-altered organs per chicken showing lymphomas.

The results are summarized in Tables 1 and 2 and presented graphically in Fig. 1 and 2.

\section{MD-Mortality}

The mortality of chickens infected experimentally with isolate VUB-83 was high, reaching $94.1 \%$ and $95.6 \%$ in Hisex and BrL chickens, respectively (Table 1. Fig. 1). Compared with the results obtained in a similarly designed experiment where the prototype MDV strain Georgia (GA) was used (Jurajda et al. 1988), the death rate after infection with VUB-83 was the same in BrL chickens, but $20 \%$ higher in Hisex chickens and as many as $40 \%$ higher in Hybro pullets.

The mean time to death was inversely proportional to the death rate: it was shortest in BrL chickens (43.1 d), slightly longer in Hisex chickens (55.5 d) and longest in Hybro pullets $(78.1 \mathrm{~d})$. Fifty $\%$ mortality occurred in BrL chickens, Hisex chickens and Hybro pullets at 46,57 and $93 \mathrm{~d}$ after infection, respectively. Similarly to the mean time to death, the incidence of gross tumours in dead chickens was also inversely proportional to the death rate: lymphomas in dead birds were significantly more frequent in Hybro pullets $(95.8 \%$ ), less frequent in Hisex chickens $(75 \%)$ and least frequent in BrL chickens (57.2\%).

All chickens that died without evidence of gross tumours showed MD-specific microscopic changes.

The mean time to death, compared with that observed after infection with strain GA, was shorter except in Hybro pullts where it was longer (78.1 d as against $60.4 \mathrm{~d}$ ). The incidence of tumours in dead birds was about $7 \%$ higher in Hybro pullets, but $2 \%$ and $18 \%$ lower in Hisex abd BrL chickens, respectively, than that recorded after infection with strain GA (Jurajda et al. 1988).

Total Incidence of MD-Lymphomas

The incidence of gross tumours after infection with isolate VUB-83 showed no 


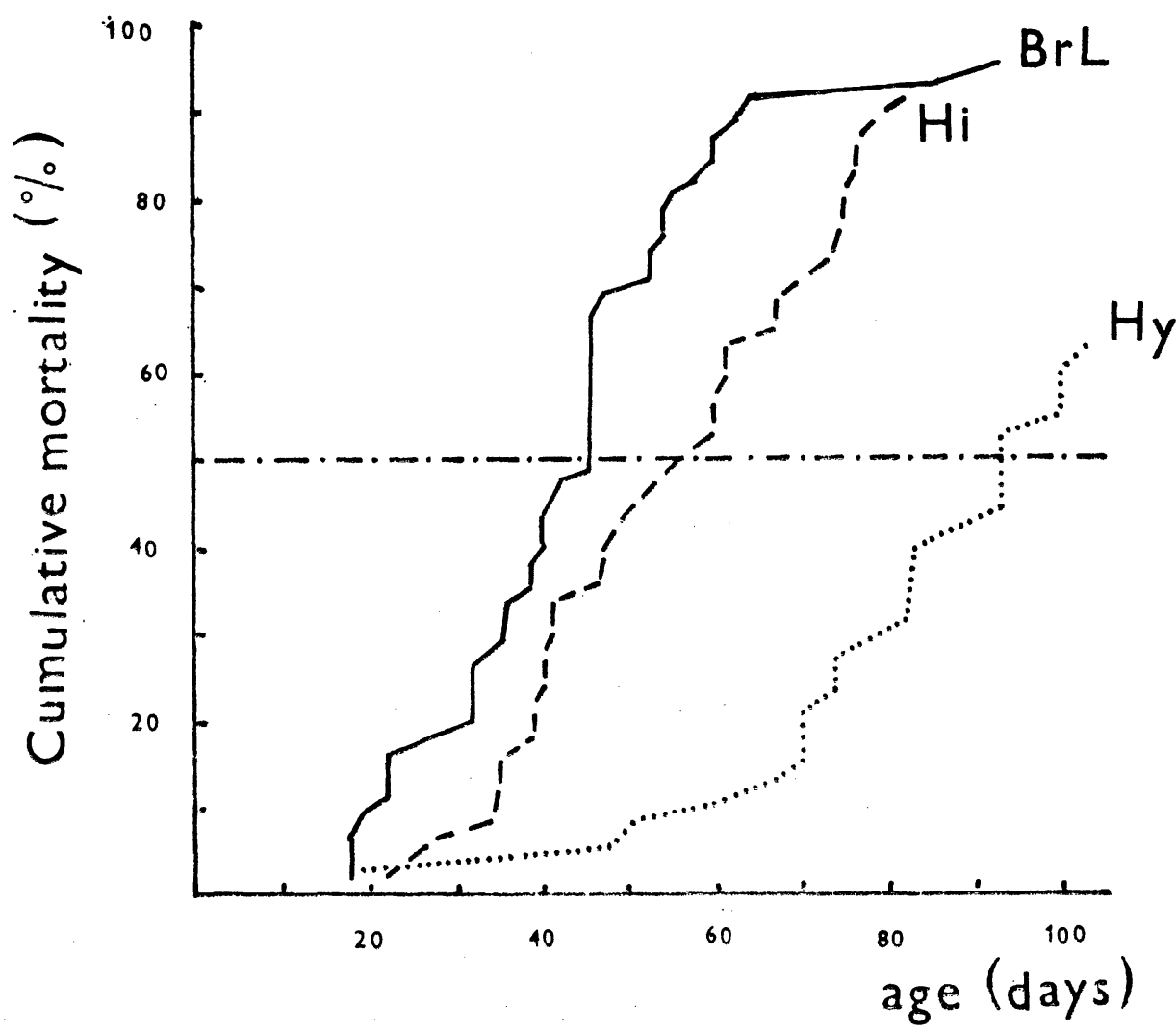

Fig. 1. Mortality of Hybro, White Hisex and Brown Leghorn chickens after infection with a field isolate (VUB-83) of Marek's disease virus

significant differences between the three groups of chickens. Altogether, lymphomas were found in $53.3 \%$ of BrL chickens, $65.8 \%$ of Hybro pullets and $70.6 \%$ of Hisex chickens. A significantly lower incidence of tumours in Hybro pullets than in Hisex and BrL chickens as was observed after infection with strain GA (Jurajda et al. 1988) was not found after infection with isolate VUB-83.

The distribution and frequency of tumours in the three groups of chickens are shown in Table 2. The organs most frequently affected with gross tumours after infection with isolate VUB-83 were the liver and the spleen in all three groups. The contribution of the genotype to the highest frequency of involvement of a particular organ was as follows: the kidney, gonads, lung and muscles were affected most frequently in Hybro pullets, the spleen and liver in BrL chickens and the heart equally in Hisex BrL chickens. The proventriculus was affected most frequently in Hisex chickens; the lung and muscles only in Hybro pullets.

Comparison of the distribution of lymphomas after infection with strain GA (Jurajda et al. 1988) and after infection with isolate VUB-83 showed a more frequent involvement of the liver and spleen and a less frequent involvement of the gonads after infection with isolate VUB-83. The tumour index (expressing the number of tumour-altered organs per chicken showing gross MD-lymphomas) was lower 


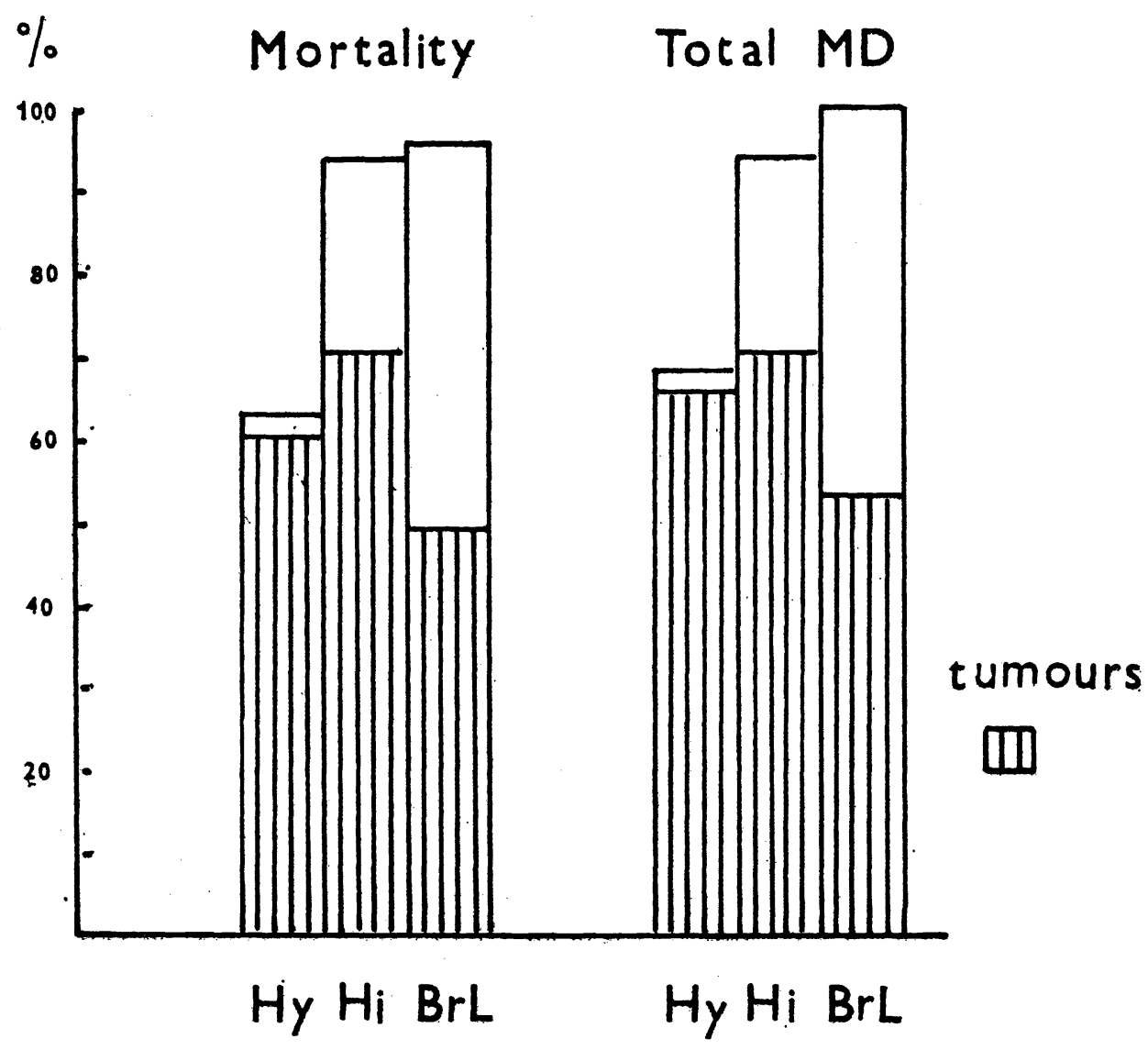

Fig. 2. Proportions of gross and microscopic changes in dead chickens and in chickens with Marek's disease after infection with a field isolate (VUB-83) of Marek's disease virus

after infection with VUB-83 than after infection with strain GA, which was probably due to a higher virulence of isolate VUB-83 and the resultant shorter interval between infection and death.

\section{Total Incidence of MD}

Using the afore-mentioned criteria, MD was diagnosed in a significantly smaller proportion of meat-type Hybro pullets $(68.4 \%$ ) than in White Hisex chickens $(94.1 \%)$ and BrL chickens $(100 \%)$. Whereas in Hybro pullets the diagnosis of MD was established mainly on the basis of gross tumour findings, in Hisex and $\mathrm{BrL}$ chickens it was based in $25 \%$ and $64.7 \%$ of the cases, respectively; on microscopic examination of the birds that died (Fig. 2).

The order of the incidence of MD in the three groups of chickens was identical to that observed after infection with strain GA (Ju ra jd a et al. 1988) but the frequency of its incidence in Hybro pullets and Hisex chickens was about $40 \%$ and $6 \%$ higher, respectively, after infection with isolate VUB-83. In BrL chickens the incidence of MD was the same as in GA strain-infected birds. A similar relation between the 
proportions of gross and microscopic MD changes was observed after infection with both MDV strains, but the contribution of microscopic changes to MD diagnosis in Hisex and BrL chickens was $16 \%$ and $23 \%$ higher, respectively, than after infection with the prototype MDV strain Geogia (Jurajda et al. 1988).

In our in-vivo experiments, field isolate VUB-83 proved to be a highly pathogenic MDV strain with increased virulence and oncogenicity both for susceptible chickens (White Hisex and $\mathrm{BrL}$ ) and for relatively more resistant types (Hybro). Isolates of similar properties were described by Witter et al. (1980), Eidson et al. (1981) and Powell and Lombardini (1986). In contrast to the findings of Witter et al. (1980), however, "the early mortality syndrome" was not observed by us in the first post-infection weeks. The object of our further studies will be a more detailed investigation of the lymphoid organs of chickens after infection with isolate VUB-83 in an attempt to confirm or exclude the presence of acute cytolytic infection of the lymphoid organs, a characteristic feature of the early mortality syndrome of chickens after infection with highly virulent pathotypes of MDV.

\section{Patogenita terénního izolátu viru Markovy nemoci (VUB-83) pro kuřata tří geneticky odlišných typů}

V laboratorních podmínkách byl sledován výskyt Markovy nemoci (MD) u 3 geneticky odlišných skupin kuřat (kuřice Hybro, finální hybrid Hisex bílý, kuřata Brown Leghorn) po parenterální infekci terénním izolátem viru MD (VUB-83). Diagnóza MD byla stanovována na základě výskytu makroskopických lymfomů nebo v případě jejich nepřitomnosti u uhynulých kuřat do 105. dne věku histologickým vyšetřením.

Výskyt MD lymfomủ u uhynulých kuřat a prủměrná doba úhynu se signifikantně lišily u všech 3 skupin v pořadí: Hybro $(95,8 \% ; 78,1$ dní), Hisex $(75 \% ; 55,5$ dní) a $\operatorname{BrL}(57,2 \% ; 43,1$ dní). Celková mortalita a výskyt MD byly signifikantně nejnižší u kư̌ic Hybro $(63,2 \%$ a $68,4 \%$ ) v porovnání s kuřaty Hisex $(94,1 \%$ a 94,1\%) a BrL $(95,6 \%$ a $100 \%)$. V celkovém výskytu MD lymfomủ nebyly zjištěny rozdíly (Hybro - 65,8 \%, Hisex - 70,6 \% a BrL - 53,3 \%). Nejčastěji nádorově postiženým orgánem po infekci izolátem V-UB-83 byly u všech testovaných kuřat játra $(34,7 \%)$ a slezina $(29,5 \%)$. Syndrom rané mortality nebyl pozorován.

\section{Патогенность полученного в полевых условиях изолята вируса болезни Марека (VUB-83) для цыпля трех генетически различных типов}

В лабораторных условиях проводились иоследования наличия болезни Марека (MD) на трех генетически различных типах цыплят (молодки Гибро, конечный гибрид Гисекс белый, цыплята Броун Легхорн) после парентералыной инфекции полученным в полевых условиях изолятом вируса болезни Марека (VUB-83). Диагноз болезни Марека определяли по наличию макроскопических лимфомов или, в случае их отсутствия, у погибыих цыплят до 105-суточного возраста - гистологическим исследованием.

Ниличие лимфомов болезни Марека у погибших цыплят и средний период их отхода существенно отличались у всех 3 групп в следующем порядке: Гибро (95,8 \%; 78,1 суток), Гисекс $(75 \% ; 55,5$ суток) и Броун Легхорн $(57,2 \% ; 43,1$ суток). Общая амертность и наличие болезни Ма- 
река были явно самыми низкими у молодок Гибро $(63,2$ и $68,4 \%$ ) по сравнению с цыплятами Гисекс $(94,1 \%$ и 94,1 \%) и Броун Легхорн $(95,6 \%$ и $100 \%$ ). В общем наличии лимфомов болезни Марека не былю установлено разхождений (Гибро - 65,8 \%, Гисекс - 70,6 \% и Броун Легхорн - 53,3 \%. Чаще всего пораженным опухолью органом после инфекции изолятом VUB-83 у всех подопытных цыплят были печень $(34,7 \%)$ и селезенпка $(29,5 \%$ \%). Синдром ранней омертности не наблюдали.

\section{References}

BIGGS, P. M. - PAYNE, L. N.: Transmission experiments with Marek's disease (fowl paralysis). Vet. Rec., 75, 1963: 177-179.

EIDSON, C. S. - ELLIS, M. N. - KLEVEN, S. H.: Reduced vaccinal protection of turkey herpesvirus against field strains of Marek's disease herpesvirus. Poultry Sci., 60, 1981: 317-322.

JURAJDA, V. - HALOUZKA, R.: Izolace patogenního viru Markovy nemoci $z$ hejna kuřic vakcinovaných krůtí herpetickou vakcínou. Vet. Med. (Praha), 33, 1988: 741-746.

JURAJDA, V. - HALOUZKA, R. - PLACHY̌, J.: Výskyt Markovy nemoci u čtyř geneticky odlišných skupin kư̌at po infekci rủznými dávkami viru Markovy nemoci - kmen GA. Vet. Med. (Praha), 34, 1989 (in press).

POWELL, P. C. - LOMBARDINI, F.: Isolation of very virulent pathotypes of Marek's disease virus from vaccinated chickens in Europe. Vet. Rec., 118, 1986: 688-691.

REISENAUER, R.: Metody matematické statistiky a jejich aplikace. SNTL - Práce, Praha $1965,208 \mathrm{p}$.

WITTER, R. L. - SHARMA, J. M. - FADLY, A. M.: Pathogenicity of variant Marek's disease virus isolants in vaccinated and unvaccinated chickens. Avian Dis., 24, 1980: 210-232. 